\title{
Learning Development of Tahfizh Al-Qur'an Based on Character Building Through Multimedia Autoplay in Class VIII SMP IT Darul Hasan Padangsidimpuan
}

\author{
Ihsan Siregar*1; Thofik Hidayat ${ }^{2}$; Rina Juliana ${ }^{3}$ \\ Universitas Muhammadiyah Tapanuli Selatan \\ Email *ikhsansiregar99@gmail.com; thofik@um-tapsel.ac.id²; \\ rinajulianaazkiya@gmail.com ${ }^{3}$
}

\begin{abstract}
The emergence of the paradigm that religious learning is not a graduation standard affects the learning of tahfizh al-Quran. So that teachers are required to be able to attract interest in tahfizh al-Qur'an at SMP IT Darul Hasan Padangsidimpuan. The use of multimedia is an option in arousing interest in learning. Burner and Edgar Dale stated that the use of interactive learning media will increase enthusiasm for learning and make it easier for students to understand learning material. Multimedia autoplay which integrates sound, images, video and text media is expected to help. the effectiveness of the process of learning tahfizh al-Qur'an. This study aims to develop learning tahfizh al-Quran based character building through multimedia autoplay in class of VIII SMP IT Darul Hasan Padangsidimpuan, because teaching and learning activities (KBM) use multi method and multimedia, but limited to the use of print media so that it seems less effective. This study also uses the method of development (research and development). Development of instructional media based on Multimedia-based Instructional Design model ADDIE (Assessment/Analysis, Design, Development, Implementation and Evaluation). The aim is to design effective and systematic learning. Media development through the situation analysis stage, media development and media creation, through design trials and subject trials. Types of qualitative and quantitative data. The data collection instrument used a trumpet and a test. Data analysis through descriptive and test data analysis. As many as 32 respondents had pretest and post-test scores, deviation freedom 30, sig.2 tailled 0.000 with 95\% confidence degree, while the pre-test mean score was 68.96 , and post-test mean score was 82.90 . The lowest score was pre-test 54 , the highest was 82, the lowest score was 70 and the highest was 90 . Based on these results, the student's score increased by 12.94 points or $18.49 \%$
\end{abstract}

Keywords: Development; Learning Tahfizh Al-Qur'an; Character Building; Multimedia Autoplay 


\title{
Fitrah \\ $\rightarrow$ Jurnal Kajian Ilmu-ilmu Keislaman
}

Vol. 6 No. 2 December 2020

\begin{abstract}
Abstrak
Munculnya paradigma bahwa pembelajaran agama bukan standar kelulusan berpengaruhterhadap pembelajaranTahfidz Al-Quran. Sehingga gurudituntutdapatmenarikminatsiswadalam tahfizh al-Qur'an di SMPIT Darul Hasan Padangsidimpuan. Penggunaan multimedia menjadi pilihan dalam membangkitkan minat belajar. Burner dan Edgar Dale menyatakan bahwa penggunaan media pembelajaran yang interaktif akan meningkatkan semangat belajar dan memudahkan siswa memahami materi pembelajaran. Multimedia autoplay yang mengintegrasikan media suara, gambar, vidio dan teks diharapkan membantu keefektifan proses pembelajaran tahfizh al-Qur'an. Penelitian ini bertujuan untuk mengembangkan pembelajaran tahfizh al-qur'an berbasis character building melalui multimedia autoplay di kelas VIII SMP IT Darul Hasan Padangsidimpuan, karena kegiatan belajar mengajar (KBM) menggunakan multimetode dan multimedia, namun terbatas pada penggunaan media cetak sehingga terkesan kurang efektif. Penelitian ini juga menggunakan metode pengembangan (research and development). Pengembangan media pembelajaran berbasis Multimedia-based Instructional Design model ADDIE (Assessment/ Analysis, Design, Development, Implementation dan Evaluation). tujuannya untuk mendesain pembelajaran yang efektif dan sistematis. Pengembangan media melaluitahap analisis situasi, pengembangan media dan pembuatan media, melalui uji coba desain dan uji coba subjek. Jenis data kualitatif dan kuantitatif. Instrument pengumpulan data menggunakan angket dan tes. Analisis data melalui analisis data deskriptif dan uji. Responden sebanyak 32 mempunyai nilai pre-test dan post-test, deviation freedom 30 nilai sig.2 tailled 0.000 dengan derajat kepercayaan 95\% sedangkan nilai rata-rata pre-tes 68.96. Nilai rata-rata post-test 82.90 . nilai terendah pre-test 54, tertinggi 82.Nilai terendah post-test 70 dan tertinggi 90 . berdasarkan hasil tersebut nilai siswa meningkat sebesar 12.94 point atau $18.49 \%$
\end{abstract}

Kata Kunci: Pengembangan; Pembelajaran Tahfizh Al-Qur'an; Character Building; Multimedia Autoplay

\section{INTRODUCTION}

The growth of Islamic education institutions, especially the Integrated Islamic School is increasingly encouraging because this institution has received tremendous welcome in the midst of the Padangsidimpuan City community because of the achievements and morals of students / inya, but on the other hand 
there are still many problems. Various problems that occur in educational institutions, be it Islamic or general educational institutions, identify moral decline which is increasingly visible at various levels of life as an indicator that education in Indonesia still needs reforms so as to produce students who have noble morals.

Facts in the field today are based on research by Rumapea, M.E.M. There are still many students who do not meet the desired expectations. Education, which is believed to be able to minimize and stem the deterioration of the morals of the nation's children, is currently still ironic, because there are still many gaps between expectations and reality in the world of education, Indonesia is facing mental problems related to character problems such as lack of discipline, likes to ignore responsibility, and far from religious values.

In the context of research on the development of multimedia autoplay through learning tahfiz al-Qur'an, the researchers chose SMP IT Darul Hasan as the place (location) for research. The rationale for choosing this school is that the school develops a new concept in the form of integral-holistic education based on monotheistic values, where students do not only learn Islam, more than that, educate them to become kaffah (near perfect) Muslims. Students are equipped with the characters (characters), skills (skills), and knowledge (knowledge) needed.

SMP IT Padangsidimpuan has implemented the 2013 Curriculum. One of the subjects that includes character is the lesson of tahfiz Al Qur'an. This school has provided a form and pattern of character education in learning tahfidz $\mathrm{Al}$ Qur'an which includes 5 characters, namely: Religious, clean, istiqomah, discipline, and patient in learning.

Based on the results of preliminary observations at SMP IT Darul Hasan by conducting interviews with Nur Habibah, as the teacher of the al-Qur'an tahfiz, he stated that character building starts from an habituation, Tahfiz alQur'an activities can form a good personality, people who do Tahfizal-Qur'an tends to good morals because morals will be a good measure in personality, especially in character building so that habituation through memorizing the Koran will form children with good character such as religious characters will be inherent in the personality of the child who participates in learning Tahfiz alQur'an. 
The results of preliminary observations required an innovation effort in learning to be able to increase students' interest in memorizing the Koran, because the habits of children today are reluctant to learn the Koran, they prefer to play games and watch cartoons. Therefore, the implementation of character building education through learning tahfiz al-Qur'an is very important so that children's memorization of the Koran can become a religious, patient, disciplined, and responsible character.

Basically, this Autoplay according to Masruri and Java Kreativity (Masruri and Java Kreativity, (2013: 34-35) is software for creating multimedia devices by integrating various types of media such as sound, images, films, videos, text and flash into a single program. Through this application, students can listen to and see the verses of the Koran through pictures, videos, flash, etc. Therefore, researchers are interested in conducting research on "the development of learning tahfizh-Al-Qur ' through character building based on multimedia autoplay at SMP IT Darul Hasan Padangsidimpuan ".

\section{RESEARCH METHODS}

The research carried out is research and development (Research \& Development) or R\&D. Research and development methods are research methods used to produce certain products and test the effectiveness of these products. To be able to produce certain products, research that is needs analysis is used and to test the effectiveness of the product so that it can function in the wider community, research is needed in order to test its effectiveness.

Through this research, the researcher tries to develop a multimedia learning product that is good and effective in the form of learning materials and media, not to test a theory. In this study, the product produced is a teaching material as an alternative to learning media. The development of this learning media is based on Multimedia-based Instructional Design using the ADDIE model which includes Assessment / Analysis, Design, Development, Implementation and Evaluation. This model was chosen to help create educational programs that are effective and have a more systematic process. 


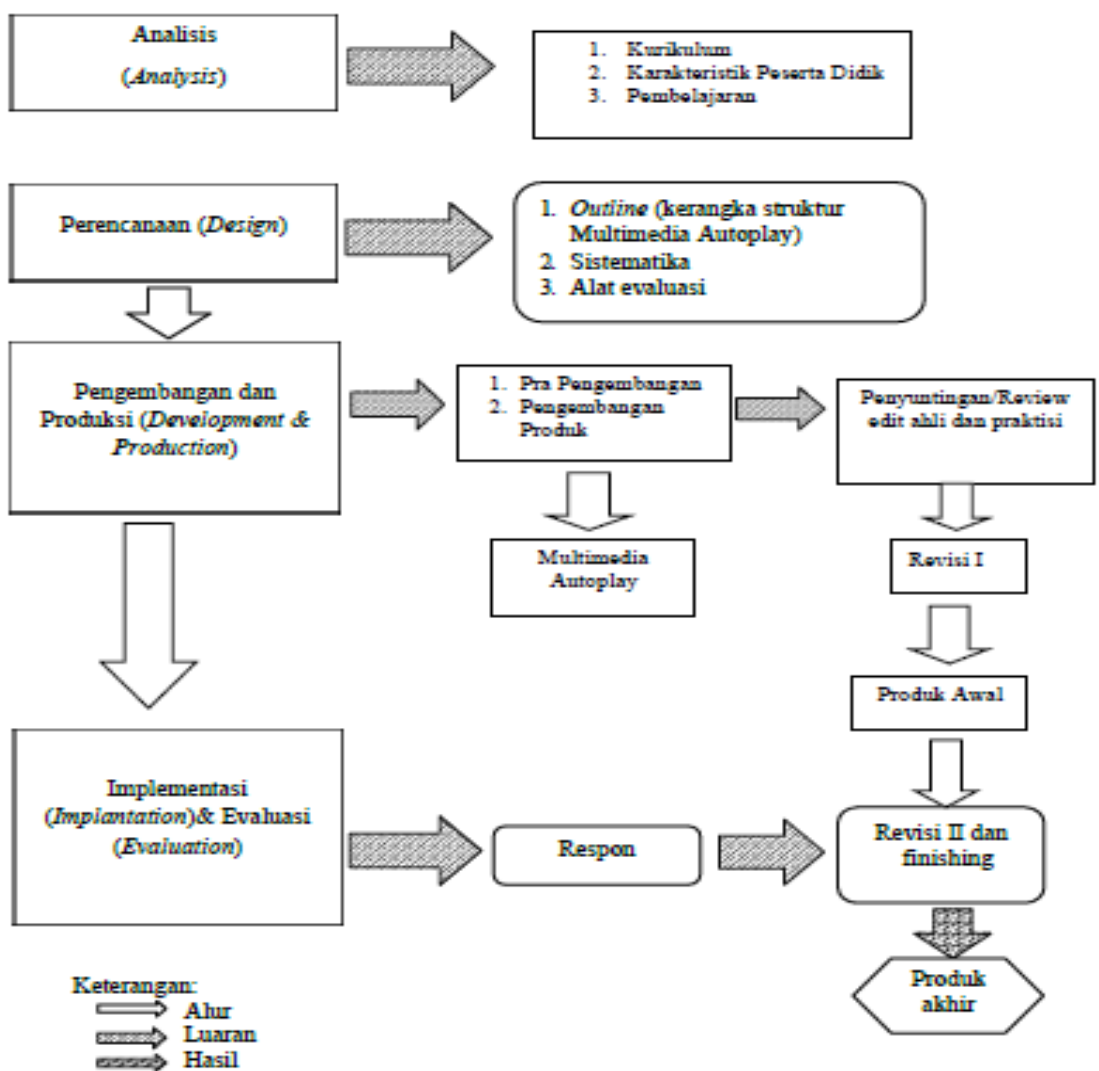

The development of autoplay-based learning media in this study uses the ADDIE model which includes Assessment / Analysis, Design, Development, Implementation and Evaluation. The following are the process stages in the ADDIE model taken from the Multimedia-based Instructional Design book by William W. Lee and Diana L. Owens:

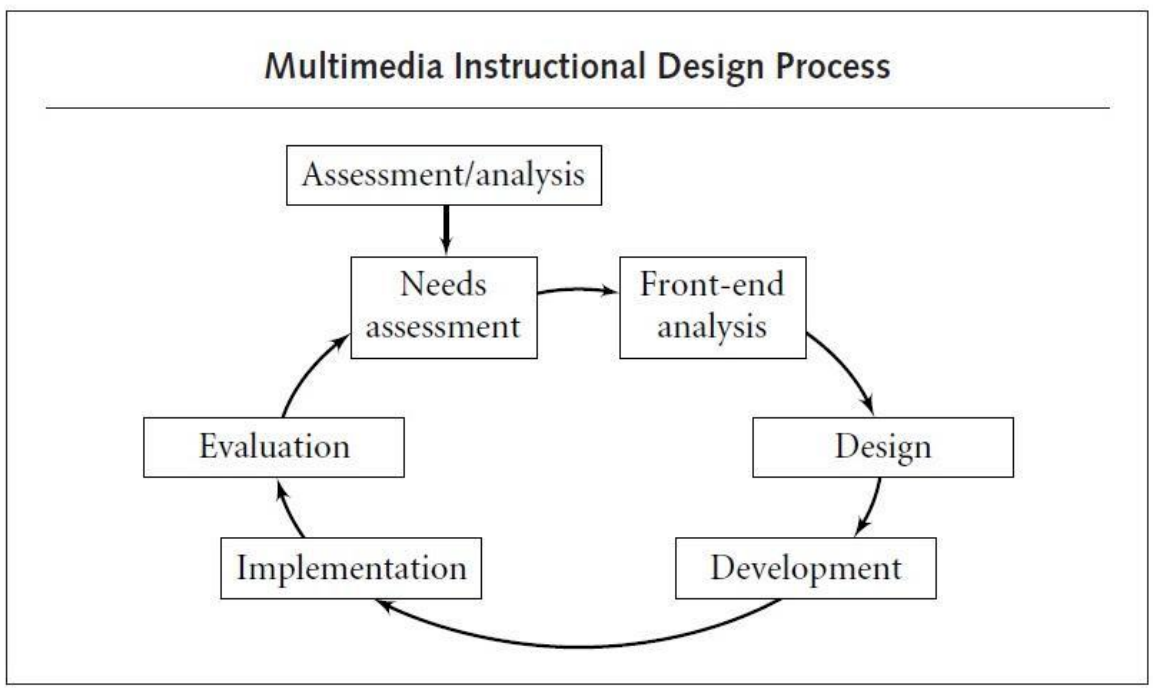

Figure 2. Multimedia Instructional Design Process 


\section{Fitrah \\ Jurnal Kajian Ilmu-ilmu Keislaman}

Vol. 6 No. 2 December 2020

At this stage of the development of Autoplay multimedia-based learning media, there are several steps that must be carried out in the research, namely:

1. Initial Situation Analysis Stage

2. Development Stage of AutoPlay Media Design

3. AutoPlay Media Making Stage

4. Multiedia AutoPlay Assessment Stage

The instrument used in data collection in this development was a questionnaire. This questionnaire is intended for assessment subjects. The purpose of using this questionnaire is to obtain qualitative and quantitative data for the perfection and feasibility of the product developed. In addition, it also uses different test tests to differentiate Pre-test and Post-test. The data analysis technique was carried out on data collection using a questionnaire on alpha and beta testing. Sampling was done using purposive sampling technique.

\section{RESEARCH DISCUSSION AND FINDINGS}

Results of Validation on the level of attractiveness and effectiveness of the product

\section{Validation of Product Interest Rate}

\section{a. Media Expert Validation and Learning Design}

Autoplay multimedia products based on character building were developed by researchers and have gone through a validation process by media experts and learning design experts. Media expert validation and learning design were carried out by Hanifah Nur Nasution, M.Kom and Rahmat fauzi Nasution, M.Kom.

The following is a description of the results of the assessment of the product.

Table 1. Answers of Media Experts and Learning Design

\begin{tabular}{clc}
\hline No & \multicolumn{1}{c}{ Criteria } & Score \\
\hline 1 & $\begin{array}{l}\text { The background design layout is very attractive and } \\
\text { appropriate by theme. }\end{array}$ & 4 \\
\hline 2 & Usage design beginner (easy use) is very easy for users & 4 \\
\hline 3 & $\begin{array}{l}\text { Size of the layout elements on the media (title, theme, } \\
\text { illustrations, logos) are in tune. }\end{array}$ & 4 \\
\hline 4 & The media layout has a clear rhythm (rythm). & 4 \\
\hline 5 & $\begin{array}{l}\text { Have a harmonious color and combination, accordingly } \\
\text { the character of the material and the target audience }\end{array}$ & 4 \\
\hline 6 & Background illustrations are able to reflect media content. \\
\hline 7 & Illustration of media content in accordance with the learning of & 4
\end{tabular}




\begin{tabular}{clc}
\hline No & \multicolumn{1}{c}{ Criteria } & Score \\
\hline & tahfizh al-Qur'an & \\
\hline 8 & $\begin{array}{l}\text { The color of the illustration corresponds to reality (natural), } \\
\text { with interesting combination. }\end{array}$ & 4 \\
\hline 9 & The quality of the illustrations is harmonious in one medium. & 4 \\
\hline 10 & $\begin{array}{l}\text { The typeface used in the content is in accordance with the } \\
\text { character of the material and according to the age level } \\
\text { the reader, simple and easy to read. }\end{array}$ & 4 \\
\hline 13 & $\begin{array}{l}\text { The font size in the instructions is easy to use } \\
\text { read. }\end{array}$ & 4 \\
\hline 14 & $\begin{array}{l}\text { The font size of the media content is according to the format / } \\
\text { size and the age level of the readers. }\end{array}$ & 4 \\
\hline 15 & $\begin{array}{l}\text { The variations of the letters are not excessive and do not use } \\
\text { decorative letters. }\end{array}$ & 4 \\
\hline
\end{tabular}

Based on table 1, media and learning design experts argue that the character building-based Autoplay multimedia learning media product developed by this researcher can be used to assist the learning of tahfizh alQur'an. Meanwhile, the level of product achievement can be calculated using the following mathematical formula.

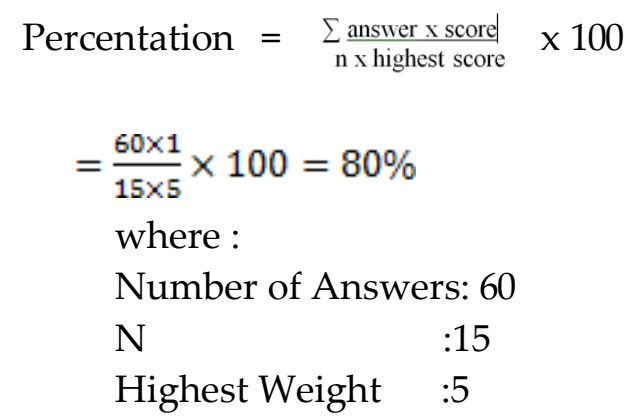

The result of the calculation of the percentage of product achievement by $80 \%$ that figure is in very good qualification and does not need to be revised.

After conducting research on multimedia-based learning media products by media experts and instructional design, then these learning media products were also assessed by material experts, namely Dr. Sungkowo, M.Pd.I. The following are the results of the material expert's response to this product.

Table 2. The material expert's response to the material content in the product

\begin{tabular}{lll}
\hline No Criteria & Score \\
\hline
\end{tabular}


1 How is the suitability of makharijul letters presented in the 4 development of Autoplay-based multimedia learning media in learning tahfizh al-Qur'an.

2 How is the suitability of the letters presented in the development of Autoplay-based multimedia learning media in learning tahfizh alQur'an.

3 How is the suitability of tajwid presented in the development of Autoplay-based multimedia learning media in learning tahfizh alQur'an.

4 How is the suitability of gharib al-Qur'an recitation presented in the development of Autoplay-based multimedia learning media in learning tahfizh al-Qur'an.

5 How muraja'ah activities of Autoplay multimedia-based learning 4 media development in learning tahfizh al-Qur'an.

6 Whether the verses of the Qur'an presented through the 4 development of character-based multimedia Autoplay based on learning tahfizh al-Qur'an can motivate students to improve their learning achievement.

$7 \quad$ What is the level of difficulty used in through the development of 5 character-based multimedia Autoplay based on learning tahfizh alQur' an according to the student's level of understanding.

8 The evaluation instrument used in the development of Autoplay- 5 based multimedia character building in learning tahfizh al-Qur'an can measure student ability

Based on table 2 experts in the field of learning materials for tahfizh al-Qur'an argue that multimedia-based learning media products developed by researchers can be used to help the learning process and the material in which is feasible to apply. Then for the level of product achievement, the percentage can be calculated using the following mathematical formula.

$\begin{array}{ll}\text { Percentation }=\underset{\mathrm{n} \times \text { highest score }}{\sum \text { answer scre }} & \times 100 \\ \text { Where : } & : 44 \\ \text { Number of Answer } & : 10 \\ \text { N } & : 5 \\ \text { Highest Weight } & \end{array}$

The result of the calculation of the percentage of product achievement of $88 \%$, this figure is in very good qualification and does not need to be revised.

b. Material Expert Validation

After conducting research on multimedia-based learning media products by media experts and instructional design, then these learning media products were also assessed by material experts, namely Dr. 
Sungkowo, M.Pd.I. The following are the results of the material expert's response to this product.

Table 3. The material expert's response to the material content in the product.

\begin{tabular}{|c|c|c|}
\hline No & Criteria & Score \\
\hline 1 & $\begin{array}{l}\text { How is the suitability of makharijul letters presented in the } \\
\text { development of Autoplay-based multimedia learning media in } \\
\text { learning tahfizh al-Qur'an. }\end{array}$ & 4 \\
\hline 2 & $\begin{array}{l}\text { How is the suitability of the letters presented in the } \\
\text { development of Autoplay-based multimedia learning media in } \\
\text { learning tahfizh al-Qur'an. }\end{array}$ & 4 \\
\hline 3 & $\begin{array}{l}\text { How is the suitability of tajwid presented in the development } \\
\text { of Autoplay-based multimedia learning media in learning } \\
\text { tahfizh al-Qur'an. }\end{array}$ & 5 \\
\hline 4 & $\begin{array}{l}\text { How is the suitability of gharib al-Qur'an recitation presented } \\
\text { in the development of Autoplay-based multimedia learning } \\
\text { media in learning tahfizh al-Qur'an. }\end{array}$ & \\
\hline 5 & $\begin{array}{l}\text { How muraja'ah activities of Autoplay multimedia-based } \\
\text { learning media development in } \\
\text { learning tahfizh al-Qur'an. }\end{array}$ & 4 \\
\hline 6 & $\begin{array}{l}\text { Whether the verses of the Qur'an presented through the } \\
\text { development of character-based multimedia Autoplay based } \\
\text { on learning tahfizh al-Qur'an can motivate students to improve } \\
\text { their learning achievement. }\end{array}$ & 4 \\
\hline 7 & $\begin{array}{l}\text { What is the level of difficulty used in through the development } \\
\text { of character-based multimedia Autoplay based on learning } \\
\text { tahfizh al-Qur'an according to the student's level of } \\
\text { understanding. }\end{array}$ & 5 \\
\hline 8 & $\begin{array}{l}\text { The evaluation instrument used in the development of } \\
\text { Autoplay-based multimedia character building in learning } \\
\text { tahfizh al-Qur'an can measure student ability. }\end{array}$ & 5 \\
\hline
\end{tabular}

Based on table 3 experts in the field of learning materials for tahfizh alQur'an argue that multimedia-based learning media products developed by researchers can be used to help the learning process and the material in which is feasible to apply. Then for the level of product achievement, the percentage can be calculated using the following mathematical formula.

Percentation $\underset{\mathrm{n} \text { xhighest score }}{\sum \text { answer scol }}=\times 100$

Where :

Number of answer: 44 
Vol. 6 No. 2 December 2020

$\begin{array}{ll}\text { N } & : 10 \\ \text { Highest weight } & : 5 \\ \text { Percentation }= & \text { x } 100\end{array}$

The result of the calculation of the percentage of product achievement of $88 \%$, this figure is in very good qualification and does not need to be revised.

\section{c. Validation of Tahfizh Teacher}

After researching multimedia-based learning media products by media experts and learning design, then these learning media products are also evaluated by material experts, then autoplay multimedia products in learning tahfizh al-Qur'an are first assessed by teachers tahfizh al-Qur ' an. Character-based multimedia autoplay product evaluation was conducted by Mr. Hikmal Nasution, S.Pd. The response questionnaire given to the teacher to obtain the assessment is basically the same as the questionnaire given to the material member. Here are the results of the tahfizh al-Qur'an teacher's response to the product.

Table 4. Tahfizh al-Qur'an Teacher's Response to CharacterBuilding-Based Multimedia Autoplay Products

\begin{tabular}{clc}
\hline No & \multicolumn{1}{c}{ Criteria } & Score \\
\hline 1 & How is the suitability of makharijul letters presented in the & 4 \\
development of Autoplay-based multimedia learning media in & \\
learning tahfizh al-Qur'an. & & \\
\hline 2 How is the suitability of the letters presented in the & 4 \\
& development of Autoplay-based multimedia learning media in \\
learning tahfizh al-Qur'an. & & \\
\hline 3 How is the suitability of tajwid presented in the development & 5 \\
& of Autoplay-based multimedia learning media in learning \\
tahfizh al-Qur'an. & \\
\hline 4 How is the suitability of gharib al-Qur'an recitation presented \\
in the development of Autoplay-based multimedia learning \\
media in learning tahfizh al-Qur'an.
\end{tabular}




\begin{tabular}{lllc}
\hline No & \multicolumn{1}{c}{ Criteria } & Score \\
\hline 7 & $\begin{array}{l}\text { What is the level of difficulty used in through the } \\
\text { development of character-based multimedia Autoplay based } \\
\text { on learning tahfizh al-Qur'an } \\
\text { according to the student's level of understanding. }\end{array}$ & \\
\hline 8 & The evaluation instrument used in the development of & 5 \\
& Autoplay-based multimedia character building in learning \\
tahfizh al-Qur'an can measure & & \\
student ability.
\end{tabular}

Based on table 4, the tahfzih al-Qur'an teachers argue that the character building-based autoplay multimedia product developed by the researcher can be used to help the learning process of tahfizh al-Qur'an and the material in it is suitable to be applied in class VIII SMP IT Darul Hasan. Padangsidimpuan. Then, for the level of product achievement, the percentage can be calculated using the following mathematical formula.

$$
\text { Percentation }=\underset{\mathrm{n} \text { xhighest score }}{\sum \text { answer } \mathrm{scol}} \underset{\mathrm{x}}{\mathrm{x}} \mathbf{1 0 0}
$$

Where :

Number of answer : 45

$\mathrm{N} \quad: 10$

Highest weight $: 5$

The result of the calculation of the percentage of product achievement of $90 \%$, this figure is in very good qualification and does not need to be revised.

\section{d. Student Feedback on CharacterBuilding-Based Multimedia Autoplay} Products

Autoplay multimedia products based on character building in the learning of tahfizh al-Qur'an developed by researchers are then applied in the learning process in the classroom using laptops and LCDs, after the learning process is complete and students can understand the lesson and can use the media correctly, the researcher gives a response to products that have been developed. The results of the student response questionnaire to the use of multimedia-based learning media are described as follows:

Item 1

\begin{tabular}{|c|c|c|c|c|}
\hline & Frequency & Percent & Valid Percent & $\begin{array}{c}\text { Cumulative } \\
\text { Percent }\end{array}$ \\
\hline Valid 4 & 24 & 76.5 & 76.5 & 76.5 \\
5 & 8 & 23.5 & 23.5 & 100.0 \\
Total & 32 & 100.0 & 100.0 & \\
\hline
\end{tabular}

Item 1 is about the ease of understanding the material of tahfizh al- 
Qur'an which is presented in a character building-based multimedia product, students' responses are $100 \%$ easy to understand. Namely 24 $(76.5 \%)$ answered easily and 7 (23.5\%) students answered very easily.

Item 2

\begin{tabular}{|c|l|c|c|c|}
\hline & Frequency & Percent & Valid Percent & $\begin{array}{l}\text { Cumulative } \\
\text { Percent }\end{array}$ \\
\hline Valid 4 & 19 & 61.3 & 61.3 & 61.3 \\
5 & 13 & 39.7 & 39.7 & 100.0 \\
Total & 32 & 100.0 & 100.0 & \\
\hline
\end{tabular}

Item 2 about the attitude of students 'pleasure in learning to use multimedia products based on character building in learning tahfizh alQur'an that has been developed, the students' responses are $100 \%$ easy to understand. Namely 19 (61.3\%) answered happy and 13 (39.7\%) students answered very happy.

Item 3

\begin{tabular}{|c|l|c|c|c|}
\hline & Frequency & Percent & Valid Percent & $\begin{array}{c}\text { Cumulative } \\
\text { Percent }\end{array}$ \\
\hline Valid 4 & 4 & 11.9 & 11.9 & 11.9 \\
5 & 28 & 88.1 & 88.1 & 100.0 \\
Total & 33 & 100.0 & 100.0 & \\
\hline
\end{tabular}

QueQuestion 3 about the spirit in memorizing juz 30 in learning tahfizh al-Qur'ân presented in multimedia product building based on character building in learning tahfizh al-Qur'an, students' response was 4 $(12.9 \%)$ answered the spirit and $27(87,1 \%)$ students answered very enthusiastically.

Item 4

\begin{tabular}{|c|c|c|c|c|}
\hline & Frequency & Percent & Valid Percent & $\begin{array}{c}\text { Cumulative } \\
\text { Percent }\end{array}$ \\
\hline Valid 4 & 11 & 33.3 & 33.3 & 33.3 \\
5 & 21 & 66.7 & 66.7 & 100.0 \\
Total & 31 & 100.0 & 100.0 & \\
\hline
\end{tabular}

Student responses to item 4 regarding grammar understanding in character building-based multimedia products in learning tahfizh al-Qur'an, student responses were 11 (33.3\%) answered easily and 21 (67.7\%) students answered very easily.

Item 5

\begin{tabular}{|l|l|l|l|l|}
\hline & Frequency & Percent & $\begin{array}{l}\text { Valid } \\
\text { Percent }\end{array}$ & $\begin{array}{l}\text { Cumulative } \\
\text { Percent }\end{array}$ \\
\hline
\end{tabular}




\begin{tabular}{|c|l|r|r|l|}
\hline Valid 4 & 14 & 46.4 & 46.4 & 100.0 \\
5 & 18 & 53.6 & 53.6 & \\
Total & 32 & 100.0 & 100.0 & \\
\hline
\end{tabular}

Item 5 discusses the attractiveness of images on character buildingbased multimedia products in learning tahfizh al-Qur'an, from the students' responses that $14(46.4 \%)$ were interesting and 18 (53.6\%) students answered very interesting.

Item 6

\begin{tabular}{|c|c|c|c|c|}
\hline & Frequency & Percent & Valid Percent & $\begin{array}{c}\text { Cumulative } \\
\text { Percent }\end{array}$ \\
\hline Valid 2 & 25 & 78.4 & 78.4 & 100.0 \\
1 & 7 & 21.6 & 21.6 & \\
Total & 32 & 100.0 & 100.0 & \\
\hline
\end{tabular}

Item 6 about motivation in using character building-based multimedia products in learning tahfizh al-Qur'an, student responses are $25(78.4 \%)$ answered disagree and $7(21.6 \%)$ students answered disagree.

\begin{tabular}{|c|l|c|c|l|}
\hline & Frequency & Percent & Valid Percent & $\begin{array}{l}\text { Cumulative } \\
\text { Percent }\end{array}$ \\
\hline Valid 4 & 15 & 46.2 & 46.2 & 100.0 \\
5 & 17 & 53.8 & 53.8 & \\
Total & 32 & 100.0 & 100.0 & \\
\hline
\end{tabular}

Item 7 is about the ease of instructions in using character buildingbased multimedia products in learning tahfizh al-Qur'an "student responses, namely $15(46.2 \%)$ answered easily and $17(53.8 \%)$ students answered very easily.

Item 8

\begin{tabular}{|c|l|c|c|c|}
\hline & Frequency & Percent & Valid Percent & $\begin{array}{c}\text { Cumulative } \\
\text { Percent }\end{array}$ \\
\hline Valid 4 & 3 & 9.6 & 9.6 & 100.0 \\
5 & 28 & 90.4 & 90.4 & \\
Total & 31 & 100.0 & 100.0 & \\
\hline
\end{tabular}

Item 8 is about the ease of understanding the instructions for seeing the law of Tajweed in multimedia products based on character building in learning tahfizh al-Qur'an „, student responses are 3 (9.5\%) easy answers and $28(90.4 \%)$ students answer very easily . 


\section{Fitrah \\ Jurnal Kajian Ilmu-ilmu Keislaman}

Vol. 6 No. 2 December 2020

Item 9

\begin{tabular}{|c|c|c|c|c|}
\hline & Frequency & Percent & Valid Percent & $\begin{array}{c}\text { Cumulative } \\
\text { Percent }\end{array}$ \\
\hline Valid 4 & 6 & 18.4 & 18.4 & 100.0 \\
5 & 26 & 81.6 & 81.6 & \\
Total & 32 & 100.0 & 100.0 & \\
\hline
\end{tabular}

Item 9 is about the ease of viewing the surah and its translation for multimedia products based on character building in learning tahfizh alQur'an „the students' responses were 6 (18.4\%) answered easily and 26 (81.6\%) students answered very easily.

\begin{tabular}{|c|c|c|c|l|}
\hline & Frequency & Percent & $\begin{array}{l}\text { Valid } \\
\text { Percent }\end{array}$ & $\begin{array}{l}\text { Cumulative } \\
\text { Percent }\end{array}$ \\
\hline Valid 4 & 23 & 75.2 & 74.2 & 100.0 \\
5 & 8 & 24.8 & 25.8 & \\
Total & 32 & 100.0 & 100.0 & \\
\hline
\end{tabular}

Item 10 is based on the results of the multimedia-based learning media product trial to help students memorize the Qur'an with details of 23 (75.2\%) answering helpful and $8(24.8 \%)$ students answering very helpful.

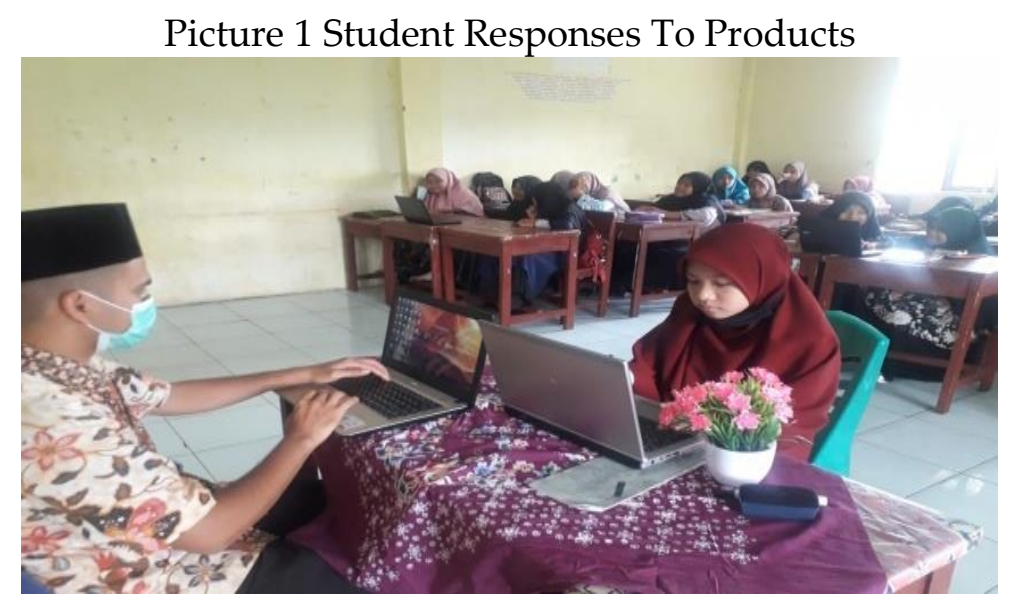




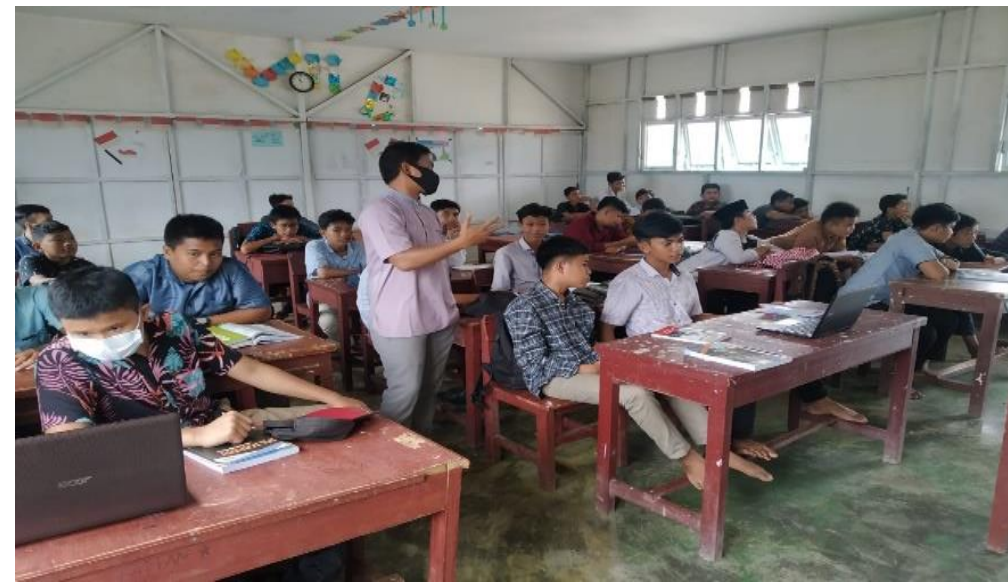

\section{Validation of Product Effectiveness Level}

\section{a. Field Test Results}

Teaching and learning activities at SMP IT Darul Hasan Padangsidimpuan start at 07.00-14.00 WIB. However, the activities of the school community started at 06.30 WIB. The picket teacher on duty is already at the front desk of the teacher room to monitor the students who will enter the classroom.

Students enter the classroom and begin with individual deposits to memorize the verses of the Koran, which is a routine that must be carried out at SMP IT Darul Hasan Padangsidimpuan. About 15 minutes of time is allocated for recitation of Al-Qur "an, then students learn according to the schedule of subjects in the first hour of each class.

Learning tahfizh al-Qur'an in class VIII SMP IT Darul Hasan is carried out 1 meeting in 1 week with an allocation of 1 lesson hour (JP) or $1 \times 45$ minutes in each meeting. The specified time duration refers to the rules of the 2013 Curriculum (K-13) because at SMP IT Darul Hasan applies the curriculum.

The conditions of teaching and learning activities in the learning of tahfizh al-Qur'an in class VIII SMP IT Darul Hasan looked different from the previous meeting. At that time the teacher applied conventional learning methods which tended to be at the teacher center and the students were conditioned to memorize the Qur'an alone without any media that attracted students' interest. However, at this meeting it was seen that the students were more enthusiastic, enthusiastic and happy to learn in the classroom because the teacher tried to implement multimedia-based interactive learning, which is a media that combines elements of text, graphics, sound, 
animation and video delivered using a computer or laptop that is then connected to the projector's LCD.

\section{b. Responden Caracteristic}

Based on the results of data processing, information was obtained about the characteristics of students in class VIII SMP IT Darul Hasan Padangsidimpuan, namely the total number of students was 32 students consisting of 15 girls and 17 boys.

Table 5. Gender

\begin{tabular}{|l|l|c|l|l|}
\hline Valid & Frequency & Percent & Valid Percent & Cumulative Percent \\
\hline Boys & 17 & 52.7 & 52.7 & 100.0 \\
Perempuan & 15 & 47.3 & 47.3 & \\
Total & 32 & 100.0 & 100.0 & \\
\hline
\end{tabular}

\section{Exposure of T-Test Result Data (Pre-test and Post-test)}

The results of the $t$ test were used to determine the level of difference in the mean value obtained by students between before treatment and after treatment. In this study, the treatment was in the form of using autoplay multimedia based on character building in learning tahfizh al-Quran as a means of increasing interest, motivation and student learning outcomes in the eyes of SMP IT Darul Hasan Padangsidimpuan. For students' interest and motivation to learn has been described in the sub-section of product trial results and student responses. While the learning outcomes use the results of memorizing deposits before and after being given treatment. The value of memorizing deposits before being treated is obtained from a written test that has been carried out by the subject teacher, while the value of daily tests after being given treatment is taken from the interactive test results available in the product. The results of the pretest and post-test trials are listed in the following table:

Table 6. Results of Pre-test and Post-test

\begin{tabular}{llrr}
\hline No & \multicolumn{1}{c}{ Name } & $\begin{array}{c}\text { Pre-test } \\
(\mathbf{X 1})\end{array}$ & Post-test (X2) \\
\hline 1 & Abdurrohim Saputra Wijaya & 65 & 85 \\
\hline 2 & Ahmad Faiz Raihansyah & 69 & 90 \\
\hline 3 & Naila Salsabil Dalimunthe & 55 & 85 \\
\hline 4 & Dea Amanda Tanjung & 70 & 90 \\
\hline 5 & Ary Arya & 65 & 80 \\
\hline
\end{tabular}




\begin{tabular}{|c|c|c|c|}
\hline 6 & Yunita Amelia & 82 & 80 \\
\hline 7 & Lili Ramadhani & 69 & 80 \\
\hline 8 & Ahmad Taufik & 65 & 80 \\
\hline 9 & Awaluddin Sitompul & 75 & 80 \\
\hline 10 & M. Adib & 65 & 80 \\
\hline 11 & Nurul Maulida & 80 & 90 \\
\hline 12 & Fasya & 65 & 80 \\
\hline 13 & Nur Anisa & 69 & 80 \\
\hline 14 & Nabila Ramadhani & 55 & 70 \\
\hline 15 & Risa Fadilah & 70 & 85 \\
\hline 16 & Elda Riska & 65 & 90 \\
\hline 17 & Doni Setiawan Raja & 82 & 85 \\
\hline 18 & Fachri Yasin & 69 & 90 \\
\hline 19 & Lu'Luah Nabila Chaniago & 65 & 80 \\
\hline 20 & Anif Rahmat Harahap & 75 & 80 \\
\hline 21 & Khabirul Eza & 80 & 80 \\
\hline 22 & Ananda Tasya & 72 & 80 \\
\hline 23 & Riski Ananda & 70 & 80 \\
\hline 24 & Fatimah Az-Zahra & 70 & 80 \\
\hline 25 & Maulida Husna & 61 & 85 \\
\hline 26 & Nanda Fitria & 70 & 90 \\
\hline 27 & Siti Khadijah & 70 & 85 \\
\hline 28 & Naila Husna & 72 & 90 \\
\hline 29 & Riski Pratama & 80 & 80 \\
\hline 30 & Fikri Ramadhan & 65 & 80 \\
\hline 31 & Ibrahim Saleh & 69 & 80 \\
\hline 32 & Rahmat Hidayat & 55 & 80 \\
\hline$\sum$ & & 2209 & 2650 \\
\hline
\end{tabular}

Based on the table in the bag where, after the students obtained the multimedia product autoplay juz 30, the students' memorization level test was carried out through a test with interactive quis creator There are 10 verses that must be memorized with a total score of 100 after being converted. After the values were collected and documented, the researcher processed the data using SSS 22, namely the one group $t$ test (pre-test and post-test). The test results can be seen in the following table. 
Tabel 7. Tabel one sample statistics and one sample statistic

One sample statistics

\begin{tabular}{lllll}
\hline & $\mathrm{N}$ & Mean & $\begin{array}{l}\text { Std. } \\
\text { deviation }\end{array}$ & Std.Error Mean \\
\hline Pre-tes & 32 & 68.96 & 7.23 & 1.388 \\
Post- tes & 32 & 83.90 & 6.85 & 1.156 \\
\hline
\end{tabular}

One sample test.

\begin{tabular}{|c|c|c|c|c|c|c|}
\hline & \multicolumn{4}{|c|}{ Test Value $=0$} & & \\
\hline & \multirow{2}{*}{$\mathrm{t}$} & \multirow{2}{*}{ Df } & \multirow{2}{*}{ Sig.(2-tailed) } & \multirow{2}{*}{$\begin{array}{c}\text { Mean } \\
\text { Difference }\end{array}$} & \multicolumn{2}{|c|}{$95 \%$ CID } \\
\hline & & & & & Lower & Upper \\
\hline Pre-tes & 54.320 & 30 & .000 & 69.967 & 67.33 & 72.59 \\
\hline Post- tes & 78.445 & 30 & .000 & 82.903 & 80.74 & 85.06 \\
\hline
\end{tabular}

The one-sample statistics and one-sample test tables show that the number of respondents (students) as many as 32 all already have pre-test and post-test scores, deviation freedom $30 \mathrm{sig} .2$ tailled value 0.000 with $95 \%$ degree of confidence while the average value The students 'pre-test was 68.96 and the students' post-test mean score was 82.90 . where the lowest score for the student's pre-test was 54 and the highest was 82, while the lowest score for the post-test for the students was 70 and the highest was 90 . Based on these results it was shown that the student's score increased by 12.94 points or $18.49 \%$

\section{CONCLUSION}

The product of the development of this teaching media is an autoplay multimedia product based on character building which is used as a learning medium for teachers and students which consists of slides related to learning tahfizh al-Qur'an. This teaching media has been carried out and practiced in class VIII SMP IT Darul Hasan Padangsidimpuan based on the results of content / material tests, learning design expert tests, subject teacher tests and field tests. Each of the validation test results for the development of autoplay multimedia based on character building in learning tahfizh al-Qur'an.

Based on the product of the autoplay multimedia product based on character building in learning tahfizh al-Qur'an. It can be seen that the characteristic of the teaching media used in the learning process is the addition of practical media in the form of interactive learning multimedia by integrating various types of media such as sound, images, video, text and flash. 


\section{REFERENCES}

Arif Muzayin Sofyan, "Character Building Melalui Pendidikan Agama Islam" Studi Kasus di MI Miftahul Huda papungan 01 Blitar, JurnalEpistemé, 10 (1), 2015: 131-132.

Ayu Kurniawati, (2011). Pengembangan Media Pembelajaran Menggunakan Microsoft Power Point, Yogyakarta: UIN Yogyakarta.

Bohlin, et.al, Building Character in School Resource Guide, San Fransisco, Jossey Bass, 2001.

Faizah, (2017), Penggunaan Media Pembelajaran Audio Visual dalam Mata Pelajaran PKn, Anthropos: Jurnal Antropologi Sosial dan Budaya, 3 (1): 55-60.

Heinich, et.al. (1999). Instructional Media and Technologies For Learning (6th ed), USA: Merrill/Prentice Hall.

Heri Setiawan dkk, Pengembangan Multimedia Interaktif Berbasis Autoplay Sebagai Media Promosi Kesehatan Tentang Kesehatan Gigi Dan Mulut Pada Siswa Kelas V Sdn Percobaan 02 Kota Malang, Jurnal, Universitas Negeri Malang, 2017: 3.

John M. Echols \& Hassan Shadily, (2014), Kamus Inggris Indonesia, An EnglishIndonesian Dictionary, Jakarta: PT Gramedia Pustaka Utama.

Lutfi Amaliya Fuadah, Local Based Curriculum Untuk Menciptakan Generasi Yang Berkarakter Kuat, Prosiding Inovasi Pendidikan: Bunga Rampai Kajian Pendidikan Karakter, Literasi, dan Kompetensi Pendidik dalam Menghadapi Abad 21, ISBN: 978-602-6977-53-3.

Maemonah, "Pendidikan Karakter dalam Mata Pelajaran Pendidikan Agama Islam di SMP 3 Pekalongan" dalam Jurnal Penelitian, 8 (1), 2011: 112-113.

Masruri dan Java Kreativity, (2013). Presentasi Interaktif dengan Autoplay" Media Studio, Jakarta: Elex Media Komputindo.

Mujadidul Islam Mafa, Jalaluddin Al-Akbar, Keajaiban Kitab Suci Al-Qur'an, Sidayu: Delta Prima Press, 2010.

Nanda Ayu Stiyawati, Prosiding Seminar Nasional Tahunan Fakultas Ilmu Sosial Universitas Negeri Medan Tahun 20171 (1), 2017: 348-352 .

Rumapea, M.E.M. (2015). Urgensi Pendidikan Karakter Perguruan Tinggi, Jurnal Pendidikan Ilmu-Ilmu Sosial, 7 (1) (2015): 49-59. 


\section{Fitrah \\ $\triangle$ Jurnal Kajian Ilmu-ilmu Keislaman}

Vol. 6 No. 2 December 2020

Sugiyono, (2011), Metodologi Penelitian Pendidikan: Pendekatan Kualitatif, Kuantitatif dan RED, Bandung: Alfabeta.

Zulfitria, Peranan Pembelajaran Tahfidz Al-Quran Dalam Pendidikan Karakter di Sekolah Dasar, Naturalistic: Jurnal Kajian Penelitian Pendidikan dan Pembelajaran 1 (2) 2017: 124-134. 